\title{
The Impact Of Viral Marketing On Corporate Brand Reputation
}

\author{
Lawrence Mpele Lekhanya, Durban University of Technology, South Africa
}

\begin{abstract}
This paper reports on the impact of viral marketing on corporate brand reputation. The study aimed to analyse and evaluate the use of viral marketing and the impact it has on the reputation of corporate branding of South African companies. The study was conducted in four South African provinces. The sample consisted of 75 companies, selected using a stratified sampling method, with respondents completing a five-point Likert scale questionnaire with the assistance of an interviewer. The results revealed that the majority of respondents were either neutral or disagreed that people make positive comments about their companies via viral marketing.

The paper will benefit company managers, marketing managers, company owners, and all affiliated stakeholders in emphasizing a new way to consider future viral marketing strategies, understanding its impact on corporate brand reputation, and how to manage negative comments pertaining to corporate brand reputation. Most work on viral marketing has concentrated on viral marketing campaigns, with little emphasis on the impact of viral marketing on corporate brand reputation. The findings are limited by the study's exploratory, quantitative nature and small sample. Generalizing should be done with care and further research with larger samples and consideration of other provinces is therefore recommended.
\end{abstract}

Keywords: Viral Marketing; Corporate Brand; Brand Reputation

\section{INTRODUCTION}

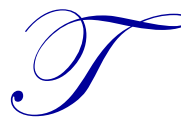

he Internet plays a crucial role in building corporate brand reputation all over the world in today's market. According to Singha, Veron-Jackson, and Cullinane (2008), the emergence, proliferation, and ubiquity of the Internet have not only transformed businesses, but also altered the relationship between business and customers. This means that the manner in which companies are communicating their brands to consumers is different from the past.

Advances in technology have helped to migrate company and consumer relationships to an interactive level, where technology contributes to brand building by creating and sustaining a long-term relationship with the customer (Singha et al., 2008). However, giving consumers the opportunity to voice their opinion will not always lead to positive word-of-mouth and can threaten companies' good image and reputation with their consumers (Wilson, 2012a). De Bruyn \& Lilien (2008) maintain that with the growth and evolution of the Internet, electronic peer-to-peer referrals have become an important phenomenon, and marketers have tried to exploit their potential through viral marketing campaigns.

Viral marketing exploits existing social media and networks by encouraging customers to share product information with their friends (Leskovec, Admic, \& Huberman, 2008). While viral marketing can help a brand grow quickly and cheaply, it carries more risk than that of building a brand based on relevance and relationships (Aaker, 2004). This marketing strategy uses customers in a specific market to promote a product (Richardson \& Domingos, 2012).

It is generally agreed that viral marketing involves the spreading of a marketing message via 'word of mouse,' ensuring that the receivers have the interest to pass along the message to their acquaintances (Kaikati \& 
Kaikati, 2004). Multiple social media formats are used in the process, which includes social networks sites such as YouTube, email communication, and many other forms of electronic media (Larson, 2009). This marketing technique on social networks and by word-of-mouth generates publicity to increase brand awareness, with the objective of using this technique being an increase in product sales through carefully designed viral processes (Borade, 2013).

\section{PROBLEM STATEMENT}

According to Pownall (2011), the great majority of business decision-makers feels it is now much more difficult to manage news flow and reputation and that the Internet, social media, and the need to respond extremely quickly are key challenges. Leskovec, Adamic, \& Huberman (2002) echo the sentiment that the inappropriate use of viral marketing can be counterproductive as it can create unfavourable attitudes toward products. Therefore, this problem requires more attention; its impact needs to be clearly understood by marketing company managers, company owners, and all affiliated stakeholders of the companies, with specific reference to South African companies.

\section{AIM AND OBJECTIVES}

\section{Aim}

The main aim of this research was to analyse and emphasise the importance of viral marketing on corporate brand reputation, evaluate the impact of viral marketing on corporate brand reputation, and the extent of the impact.

\section{Objectives}

- $\quad$ to explore the impact of viral marketing on corporate brand reputation

- to identify factors influencing the use of viral marketing to build corporate brand reputation, and to what extent these factors affect corporate brand reputation

\section{LITERATURE REVIEW}

\section{Definition of Viral Marketing}

The term 'Viral Marketing' describes the phenomenon by which consumers mutually share and spread marketing relevant information initially sent out deliberately by markets to stimulate and capitalize on word-ofmouth behaviour (Van der Lans, van Bruggen, Eliashberg, \& Wierenga, 2010). Viral marketing is viewed by some as word-of-mouth advertising in which customers tell other customers about products and services (Ehlers, in Du Plessis, Strydom, \& Jooste, 2012). Wilson (2012b) identifies the broader definition of viral marketing as any strategy that encourages individuals to pass on a marketing message to others, creating potential growth in the message's exposure and influence. He continues that, as with viruses, such strategies take advantage of rapid multiplication to explode the message to thousands and millions. Rouse (2007) maintains that viral marketing is any marketing technique that induces websites or users to pass on a marketing message to other sites or users, creating a potentially exponential growth in the message's visibility and effect. Kaplan \& Haenlein (2011) further define it as 'electronic word-of-mouth' whereby some form of marketing message related to a company, brand, or product is transmitted in an exponentially growing way, often through the use of social media applications."

\section{Corporate Brand Reputation}

The corporate brand is special because it explicitly and unambiguously represents an organization as well as a product (Aaker, 2004). Change, driven by technology, market trends, and innovation of every type, is accelerated by the company media strategy (Aaker, 2011). This translates to companies needing to be very careful about the media and media strategy they use when communicating their brands to consumers. Corporate brands and their reputations are important assets in enabling organisations to exploit opportunities and mitigate threats (Argenti and Druckenmiller, 2004). According to Abimbola and Kocak, (2007), branding and reputation-building are key 
resources that allow an organization to be successful over an extended period. Van den Bergh and Behrer (2011) indicate that marketers, who still use the old method of shouting how fantastic their companies' brand is, are not successful anymore. Today, it is crucial for marketers to listen and understand how the company's brand fits consumer lives and lifestyles. Baker (2003) finds that the managing of corporate brands needs a different approach to classic line branding. This means that while individual line branding primarily focuses on consumers and distributors and few staff interact with consumers, consumers in fact assess the brand's values from advertising, such as viral marketing campaigns, packaging, distribution, and the people using the brand. The use of the entire integrated marketing communications mix is used to create brand image and reputation, including internet and social network marketing (Jobber, 2007).

\section{Concept and Benefits of Viral Marketing}

The viral marketing concept and its examples suggest that marketers can continue to use the power of interpersonal networks to promote a product or service (De Bruyn \& Lilien, 2008). This form of customer-tocustomer communication is an effective means of transforming electronic communication networks into influencing networks (Ehlers, in Du Plessis et al., 2012). Viral marketing exploits existing social networks by encouraging customers to share product information with their friends (Leskovec, Adamic, \& Huberman, 2008).

It is evident that the viral nature of the Internet means that a negative comment about the company can spread faster than a fire in a matchbox and it is always very difficult to undo the damage done (Paul, 2007). According to a Mindcomet Corporation white paper (2008), the Internet has radically changed the concept of wordof-mouth. The term 'Viral marketing' was coined by venture capitalist Steve Jurvetson in 1997 and was used to describe Hotmail's email practice of appending advertising of themselves to outgoing user mail. The assumption is that if such an advertisement reaches 'susceptible' users, the same users will become 'infected' (i.e., sign up for an account) and then go on to infect other susceptible users.

However, Klopper (2002) indicates that the viral marketing concept enables consumers to spread information on-line or through other digital media, which challenges traditional marketing practices. Viral marking has begun to replace what was traditionally referred to as word-of-mouth (Wampole, 2012). The key driver in viral marketing is the effectiveness of unsolicited, electronic referrals to create awareness, trigger interest, and generate sales or product adoption (De Bruyn \& Lilien, 2008). According to Dobele, Toleman, \& Beverland (2005), successful viral marketing campaigns are comprised of an engaging message that involves imagination, fun and intrigue, encourages ease of use and visibility, targets credible sources, and leverages combinations of technology.

\section{Company Practice of Viral Marketing}

De Pelsmacker, Geuens, \& Van den Bergh (2010) point that viral marketing is the set of techniques used to spur brand users, game participants, or advocate consumers among the target group to promote their favourite brand to friends and relatives. They are put to work to spread the word about the brand or product by using e-mail, SMS, 'tell or send to a friend' buttons, or other referral tools on websites. Viral marketing attempts to harness the strongest of all consumer triggers - personal recommendation. The snowball principle is used in viral marketing with the typical network nature of the internet strongly supporting the quick, exponential growth in the message's exposure and its influence in a relatively effortless manner.

As with viruses, viral marketing strategies take advantage of rapid multiplication to explode the message to thousands or millions of 'victims.' Viral marketing campaigns work best between groups with strong common interests, which implies that these campaigns allow marketers to spread selective messages to selective groups. By using viral marketing tactics carefully, marketers may avoid negative reactions and gain an excellent return on investment, increasing the reach of a marketing message to a targeted group that is much larger than the audience originally covered.

Viral marketing is increasingly popular for three reasons:

- $\quad$ Entire social networks are online today as a large number of everybody's friends and family members have started to use Web 2.0, or will soon. 
- $\quad$ Conducting marketing to individuals online is virtually cost-free and it is possible for each individual to contact hundreds more without much effort or cost.

- Online posts or comments can potentially have an impact on company sales and reputation, no matter how insignificant the entry may seem to be (Rice, 2010).

Hutchings (2012) indicates that use of the new media in the commercial context can be an effective and powerful business tool because it gives companies the opportunity to convey information, promote brands or products, or make a sales pitch in a more subtle manner than traditional marketing. Once a company is on Facebook, the aspect of anonymity is no longer possible (Anon, 2011), as anyone can access confidential information about the company. The company's competition is also able to obtain this information and use it against the particular company, which can potentially damage the company's corporate reputation; moreover, social media places companies in a vulnerable position when it comes to security (Anon, 2011). Hackers, for example, can create an online swindle which can deceive people. These online swindles can pose a potential threat to a company's reputation because people will be deceived and the company will be held responsible for whatever damage the swindle may have caused.

\section{Elements of Viral Marketing Strategy}

Wilson (2012a) highlights the following important elements of viral marketing:

- $\quad$ Give away products and service: Most viral marketing programs give away valuable products or services to attract attention.

- $\quad$ Easy transfer to others: A viral marketing message must be easy to transfer and replicate via email, website, graphic, or software downloads.

- $\quad$ Scalability from small to very large: To spread like wildfire, the transmission method must be rapidly scalable from small to very large.

- Exploit motivation and behaviours: Clever viral marketing plans take advantage of common human motivation.

- $\quad$ Take advantage of other's resources: The most creative viral marketing plans use others' resources to get the word out.

- Utilising existing communication networks: A person's broader network may consist of scores, hundreds or thousands of people, depending upon his or her position in society.

\section{Viral Marketing and Internal/External Environment}

Marketing is important in the early, vulnerable years of business, as it provides a vital interface between the firm and its external environment (Stokes, 2000). According to Fatoki and Garwe (2010), South African businesses are severely affected by internal (access to finance, management skills, networking, investment information technology, and cost of production) and external (economic environment, markets, infrastructure, technology, political and legal, socio-demographics, and regulations) environmental factors that can and will have an impact on a business communication strategy with its potential customers.

The most important thing for the company is to analyse the environment of marketing in such a way that company plans can be met in time. South African companies need to be aware of changes in the external environment, which include changes taking place in the economic, social, political, technological, and international environment (Cant \& Wiid, 2013). External or societal factors that surround a community, consciously or subconsciously, influence the nature of the community's interpersonal interactions, such as geography, religion, or economics, in their buying decision-making process (Brown \& Fiorella, 2013).

\section{Damage Control in Viral Marketing}

Bradly and Honey (2007) stress that it is not possible to establish the cost of damage to a company's reputation before an event. This is partly because the magnitude is dependent on the prior state of reputation, the 
nature of the threat, and the way the situation is handled. Viral marketing uses electronic communication to trigger brand message throughout a widespread network of buyers (Dobele et al., 2005). This process is often portrayed as a random ground-up phenomenon over which marketers have little control. It is very important to monitor what is being said about the company online in order to implement the necessary reputation management (Rice, 2010).

The positive impact viral marketing could have on the company can be enormous, but it can have a negative impact as well (Bryant, 2010). This could lead to unsatisfied customers who could spread the word about the company very quickly. A long-time negative review of a company that is left without resolution could cause damage to the company, which is where the importance of reputation management comes into play. Young and Burgess (2010) support the premise that brand management for a service company is about dealing with the corporate brand, the name, and reputation of the company itself.

\section{RESEARCH METHODOLOGY}

Research was conducted to collect data from South African companies operating in different provinces. Primary data were collected from 75 South African companies and private, public, and government companies were targeted for this study. Since a suitable sampling frame was available, from which to draw a probability sample, a stratified sampling approach was used to select respondents from four provinces; namely, from the Eastern Cape, North West, KwaZulu-Natal, and Gauteng provinces. A list of registered companies and their physical addresses, obtained from the department of South African Trade and Industry, was used to select the companies.

The literature review was used as the source of information to formulate the questionnaire, while a combination of closed- and open-ended questions was used. Space was provided at the end of each question as a means of inclusion of any other open-ended questions in order to obtain relevant information. The final usable sample is shown in Table 1, in terms of stratum control characteristics. A mixed approach of qualitative and quantitative techniques was used to collect primary data. In order to standardise the conditions under which the questionnaires were completed, research assistants in the selected provinces were recruited and trained as field workers. Questionnaires were hand-delivered to 75 companies in four provinces, with interviews conducted in the Eastern Cape, North West, KwaZulu-Natal, and Gauteng Provinces. Table 1 is a profile of the final usable sample.

Table 1: Profile of Usable Sample as per Stratum Characteristics

\begin{tabular}{|l|c|c|}
\hline \multicolumn{1}{|c|}{ Area } & Frequency & Percentage \\
\hline \multicolumn{1}{|c|}{ Araphical Area } & 15 & 20 \\
\hline Eastern Cape Province & 14 & 19 \\
\hline North West Province & 25 & 28 \\
\hline KwaZulu - Natal Province & 21 & 100.0 \\
\hline Gauteng Province & 75 & Percentage \\
\hline Total & & 31 \\
\hline \multicolumn{1}{|c|}{ Turnover pa } & Frequency & 36 \\
\hline Company Size & 23 & 20 \\
\hline \multicolumn{2}{|c|}{} \\
\hline R 0 - 50000 & 27 & 13 \\
\hline R50001 -10000 & 15 & \\
\hline R10001-150000 & 10 & \\
\hline And above & & \\
\hline
\end{tabular}

The geographic area in which the respondents' companies are located is illustrated in Table 1, as is the sales turnover per year category in which the company falls. In this regard, sales turnover is defined as the gross sales revenue per year, before expenses and taxes. The table shows a reasonable spread across the four geographic areas between companies in the different provinces.

A literature review was used to develop the questionnaire, which was later used as the measuring instrument for this study. Table 2 summarises the main questions used to collect primary data. 
Table 2: Summary of Key Questions

\begin{tabular}{|c|c|}
\hline Research Area & $\begin{array}{l}\text { Question } \\
\end{array}$ \\
\hline Customer orientation & $\begin{array}{l}\text { Viral marketing gives customers freedom to talk about the company. } \\
\text { Response alternative: } 5 \text { point likert scale }\end{array}$ \\
\hline $\begin{array}{l}\text { Customer attitudes towards } \\
\text { company }\end{array}$ & $\begin{array}{l}\text { People make positive comments via viral marketing about the company. } \\
\text { Response alternative: } 5 \text { point likert scale }\end{array}$ \\
\hline $\begin{array}{l}\text { Understanding of viral } \\
\text { marketing }\end{array}$ & $\begin{array}{l}\text { Who performs the marketing role in your business? } \\
\text { Response alternatives: Marketing manager; Salesman, Owner/manager; No - one } \\
\text { What is your understanding of Viral marketing? } \\
\text { Response alternatives: Telephone marketing; mass media marketing; online marketing; } \\
\text { word-of-mouth online marketing; social media network marketing. }\end{array}$ \\
\hline $\begin{array}{l}\text { Factors influencing viral } \\
\text { marketing abilities/activities }\end{array}$ & $\begin{array}{l}\text { What affects your viral marketing abilities/activities? } \\
\text { Response alternatives: Limited funds; I do not know why my company should do viral } \\
\text { marketing; Lack of knowledge and experience; I never thought about viral marketing. }\end{array}$ \\
\hline $\begin{array}{l}\text { Environmental factors } \\
\text { influencing viral marketing }\end{array}$ & $\begin{array}{l}\text { Which one of the following factors affects your viral marketing abilities/activities? } \\
\text { Response alternatives: financial resources; socio-demographics; Technology; Economics, } \\
\text { political and legal; competition; natural environment }\end{array}$ \\
\hline $\begin{array}{l}\text { Importance of viral marketing to } \\
\text { brand popularity }\end{array}$ & $\begin{array}{l}\text { Company gains more popularity through a Viral Marketing platform. } \\
\text { Response alternative: 5-point Likert scale }\end{array}$ \\
\hline $\begin{array}{l}\text { Importance of viral marketing to } \\
\text { marketing/marketing } \\
\text { communications success }\end{array}$ & $\begin{array}{l}\text { Viral marketing assists the company in acquiring more referrals and a good reputation. } \\
\text { Response alternative: 5-point Likert scale }\end{array}$ \\
\hline $\begin{array}{l}\text { Importance of viral marketing to } \\
\text { brand popularity }\end{array}$ & $\begin{array}{l}\text { Viral marketing created more awareness and more popularity about our brand. } \\
\text { Response alternative: 5-point Likert scale }\end{array}$ \\
\hline $\begin{array}{l}\text { Importance of viral marketing to } \\
\text { marketing/marketing } \\
\text { communications success }\end{array}$ & $\begin{array}{l}\text { Viral marketing assists us in obtaining more or better ideas for the future in } \\
\text { improvements. } \\
\text { Response alternative: 5-point Likert scale }\end{array}$ \\
\hline $\begin{array}{l}\text { Importance of viral marketing to } \\
\text { marketing/marketing } \\
\text { communications success }\end{array}$ & $\begin{array}{l}\text { Viral Marketing is used as a source of information about the business/company. } \\
\text { Response alternative: 5-point Likert scale }\end{array}$ \\
\hline Managerial implications & $\begin{array}{l}\text { It is easy to control information coming via viral marketing with regard to the company. } \\
\text { Response alternative: 5-point Likert scale }\end{array}$ \\
\hline $\begin{array}{l}\text { Importance of viral marketing to } \\
\text { marketing/marketing } \\
\text { communications success }\end{array}$ & $\begin{array}{l}\text { Information and brand reputation about our company has increased due to the use of } \\
\text { viral marketing strategies. } \\
\text { Response alternative: } 5 \text { point likert scale }\end{array}$ \\
\hline Customer orientation & $\begin{array}{l}\text { Customers understand their responsibilities of using viral marketing. } \\
\text { Response alternative: 5-point Likert scale }\end{array}$ \\
\hline Customer orientation & $\begin{array}{l}\text { Viral marketing has helped us to build a strong relationship with our target customers. } \\
\text { Response alternative: 5-point Likert scale }\end{array}$ \\
\hline Customer orientation & $\begin{array}{l}\text { Only targeted customers communicate with us through the use of viral marketing. } \\
\text { Response alternative: } 5 \text {-point Likert scale }\end{array}$ \\
\hline
\end{tabular}




\section{RESEARCH FINDINGS}

A survey was conducted with various companies from different provinces in South Africa, consisting of a total sample size of 75 companies. Analysis of data reveals the following results.

As illustrated in Figure 1, more than half of the respondents (59 percent) strongly agree that viral marketing gives customers freedom to talk about their companies. Ten (14 percent) of the respondents agree with this statement, seven (nine percent) are neutral, eight (11 percent) disagree, and five (seven percent) strongly disagree.

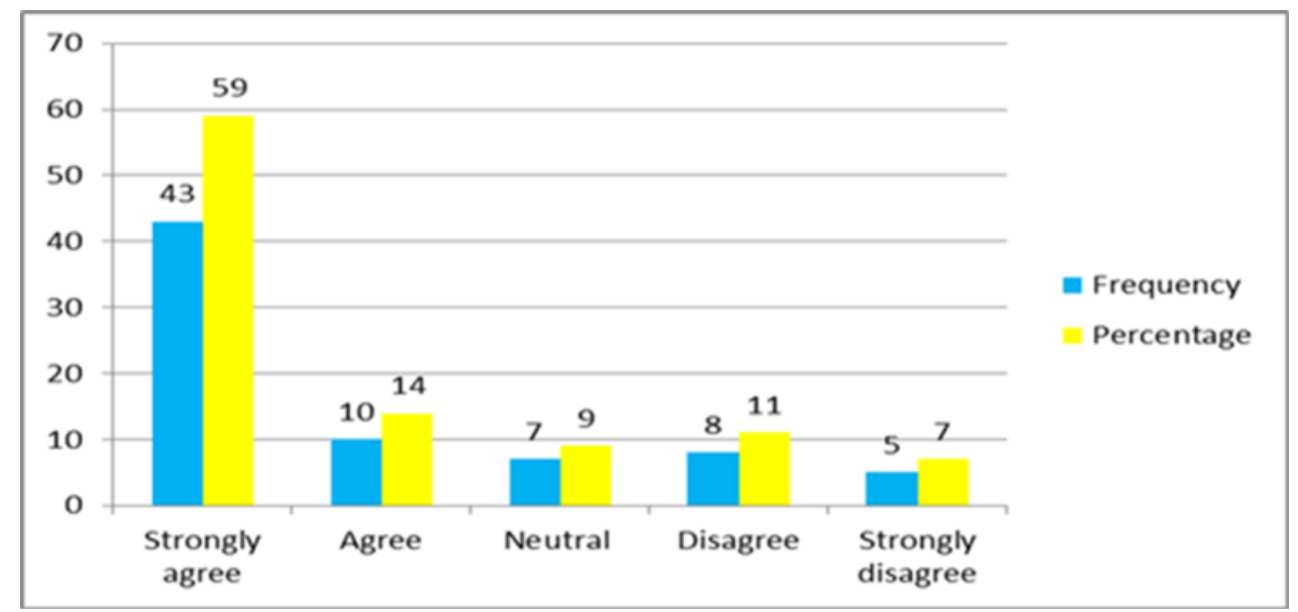

Figure 1: Viral Marketing Gives Customers' Freedom to Talk about the Company

Figure 2 shows that a large proportion of respondents 38 (54 percent) are neutral about the statement that people make positive comments via viral marketing about their companies. Only two (three percent) strongly agree with this statement, eight (11 percent) agree, 20 (29 percent) disagree, and two (three percent) strongly disagree.

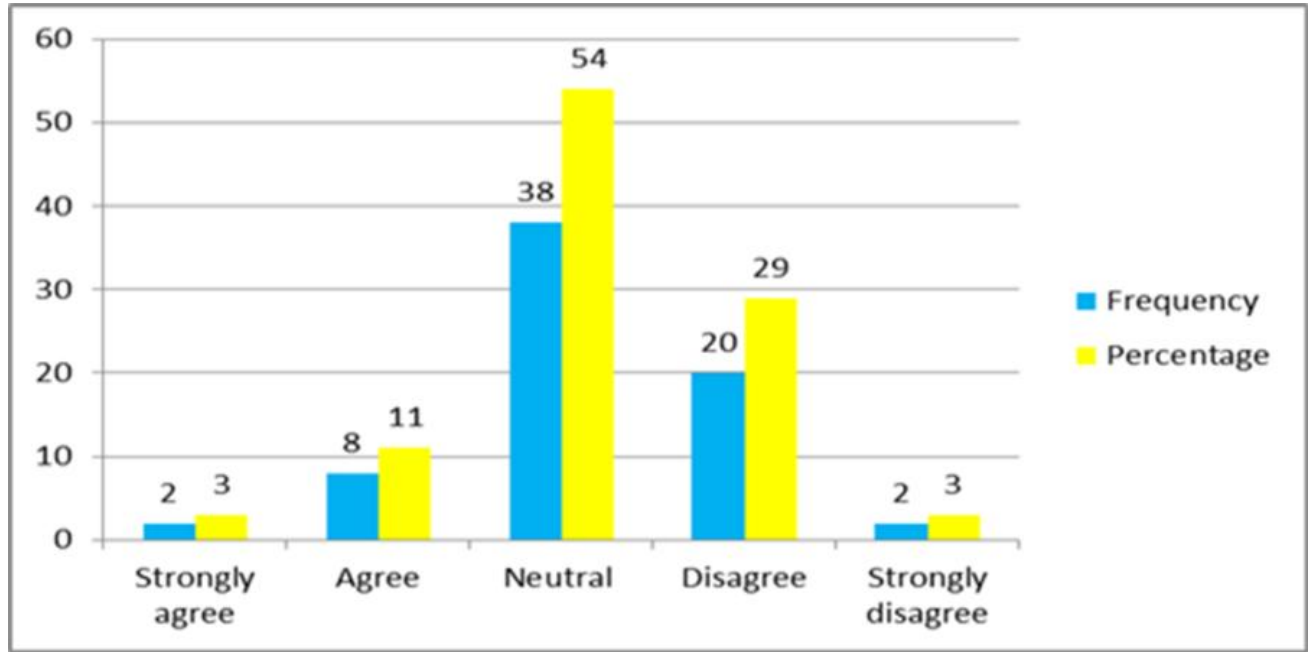

Figure 2: People Make Positive Comments via Viral Marketing about Company 
The results illustrated in Figure 3 show that a large number of respondents believe telephone marketing is viral marketing 23 (31 percent). Ten (14 percent) of the respondents indicated that, in their opinion, mass media marketing is the same as viral marketing, with 16 (21 percent) indicating that their understanding of viral marketing is that it consists of online marketing. At the same time, there were a few respondents ( 34 percent) who showed that they understand viral marketing as consisting of word-of-mouth online marketing and social media network marketing (17 and 17 percent, respectively).

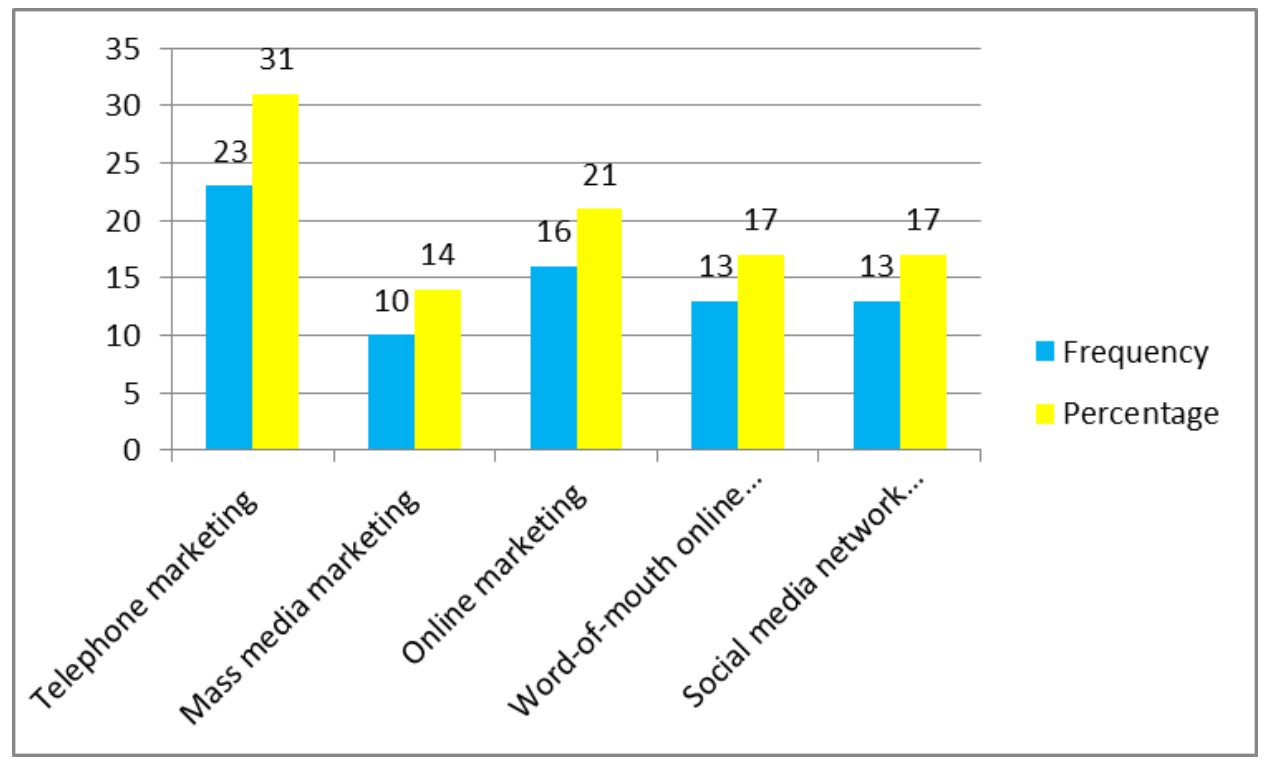

Figure 3: Respondents' Understanding of Viral Marketing

The results, as shown in Figure 4, illustrate that 38 (51 percent) indicated that marketing is done by the marketing manager, 15 (20 percent) say it is done by a salesman, 10 (13 percent) indicated it is done by the owner/manager, and 12 (16 percent) say that no one does marketing.

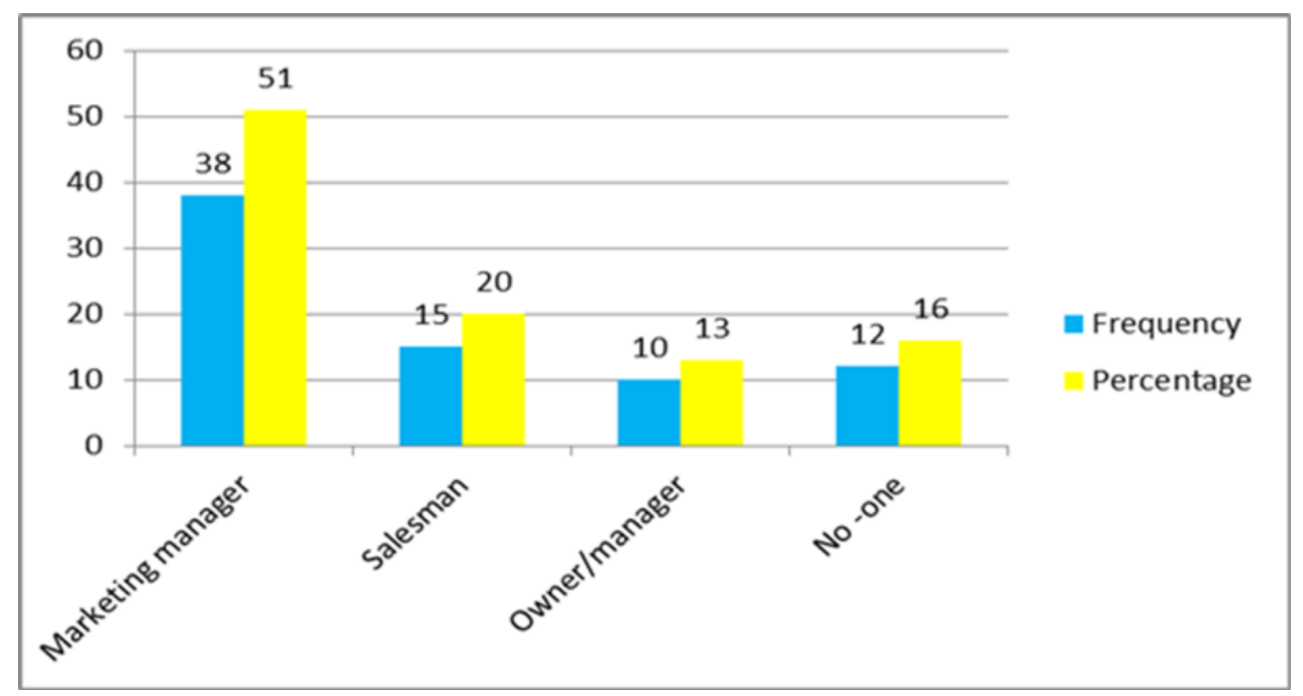

Figure 4: Who Performs Marketing Responsibilities? 
Figure 5 shows that more than half of the respondents (42) pointed to a lack of knowledge and experience of viral marketing (56 percent) and 17 (23 percent) indicated limited funds as the problem in their viral marketing abilities/activities. While six (eight percent) said they never thought about using viral marketing, 10 (13 percent) do not know why their companies should use viral marketing.

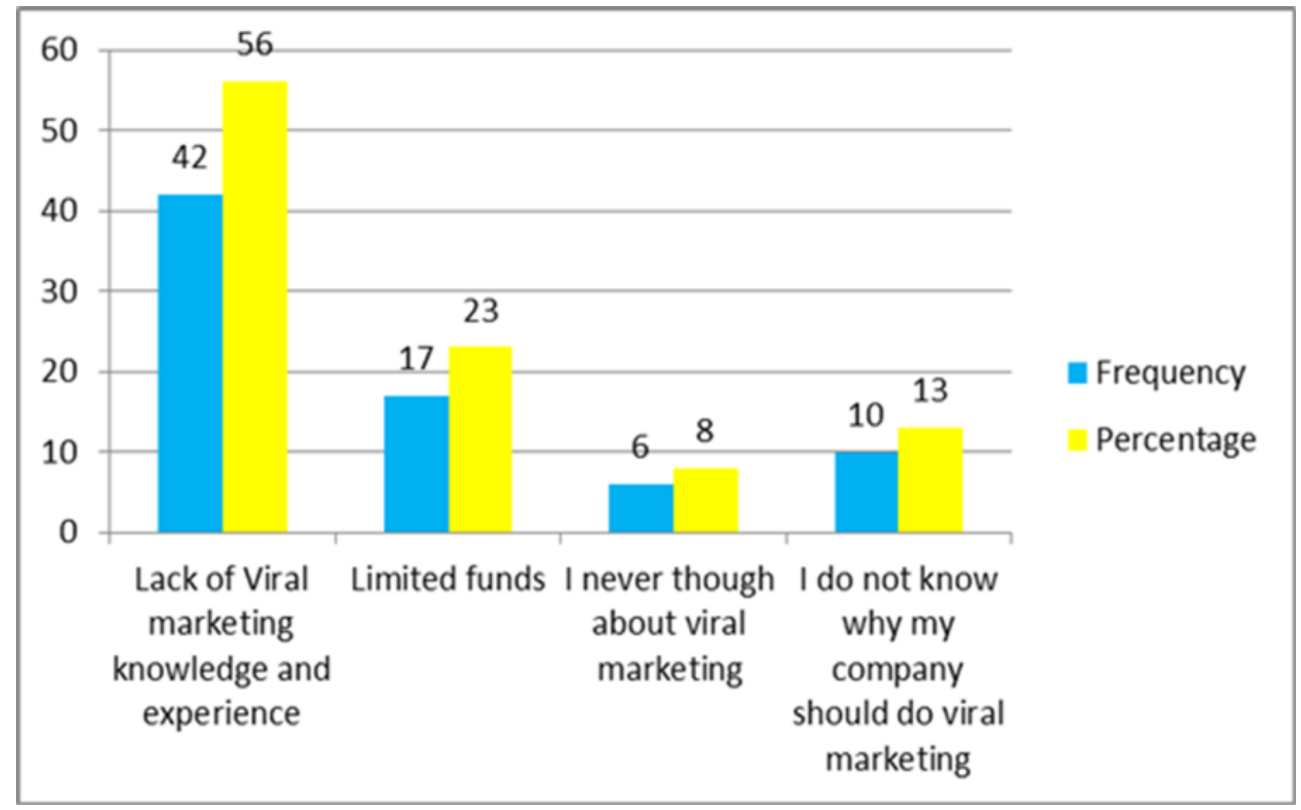

Figure 5: Respondents' Abilities/Activities of Using Viral Marketing

As shown in Figure 6, there are a number of environmental factors that affect viral marketing activities of a company, including financial resources, socio-demographics, technology, economics, political and legal, competition, and natural environment. A large number of the respondents (23) indicated financial resources (31 percent), technology 27 (36 percent), and economics 10 (13 percent) as being the main factors that affect their viral marketing activities.

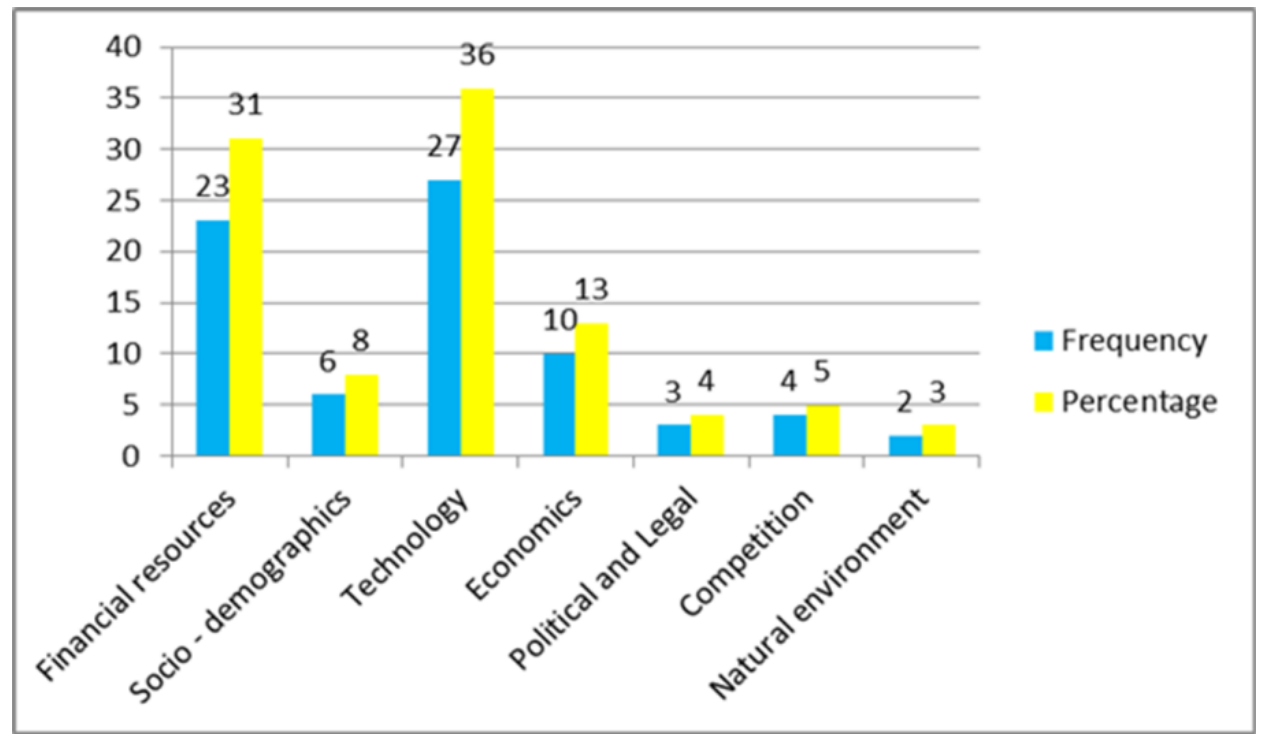

Figure 6: Environmental Factors Influencing Respondents' Use of Viral Marketing 
Figure 7 illustrates that 46 (62 percent) of the respondents agree that their companies gain more popularity through the use of a viral marketing platform. Nine (12 percent) strongly agree with this statement, 13 (17 percent) are neutral, three (four percent) disagree, and four (five percent) strongly disagree.

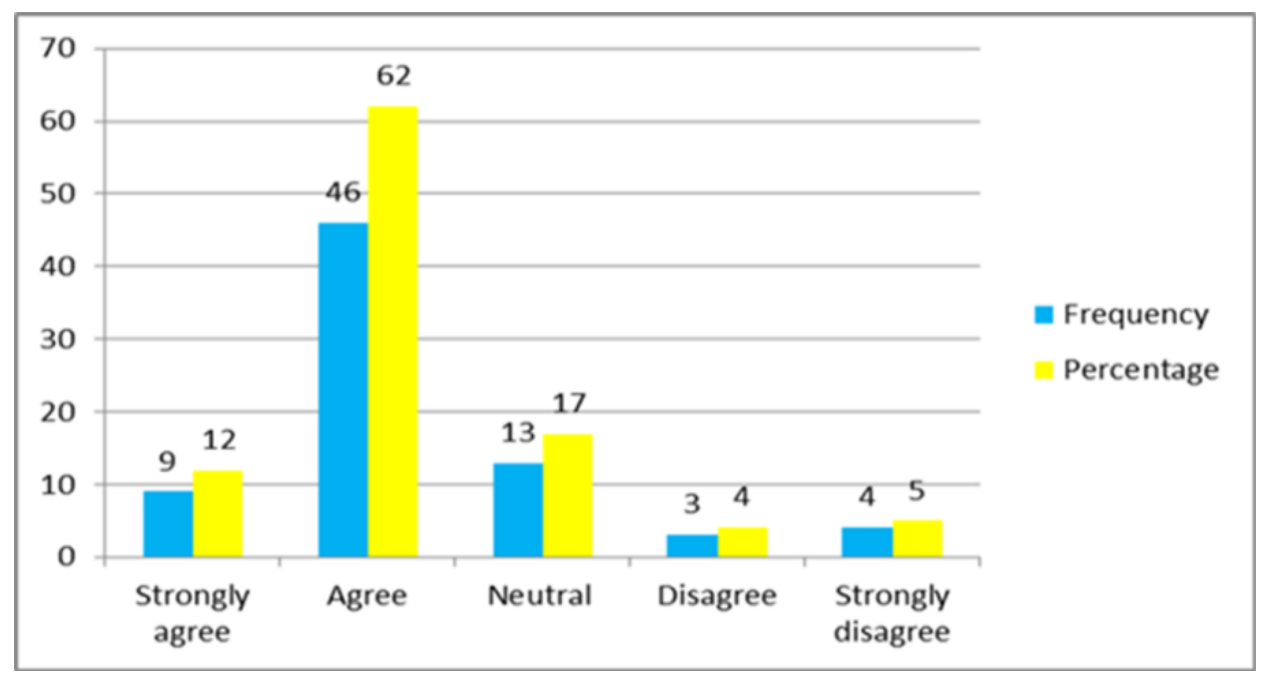

Figure 7: Company Gains More Popularity through a Viral Marketing Platform

The results, as shown in Figure 8, illustrate that 37 (50 percent) disagree and 10 (13 percent) strongly disagree that their companies acquire more referrals and a good reputation through the use of viral marketing, while 13 (17 percent) are neutral, 10 (13 percent) agree, and five (seven) strongly agree.

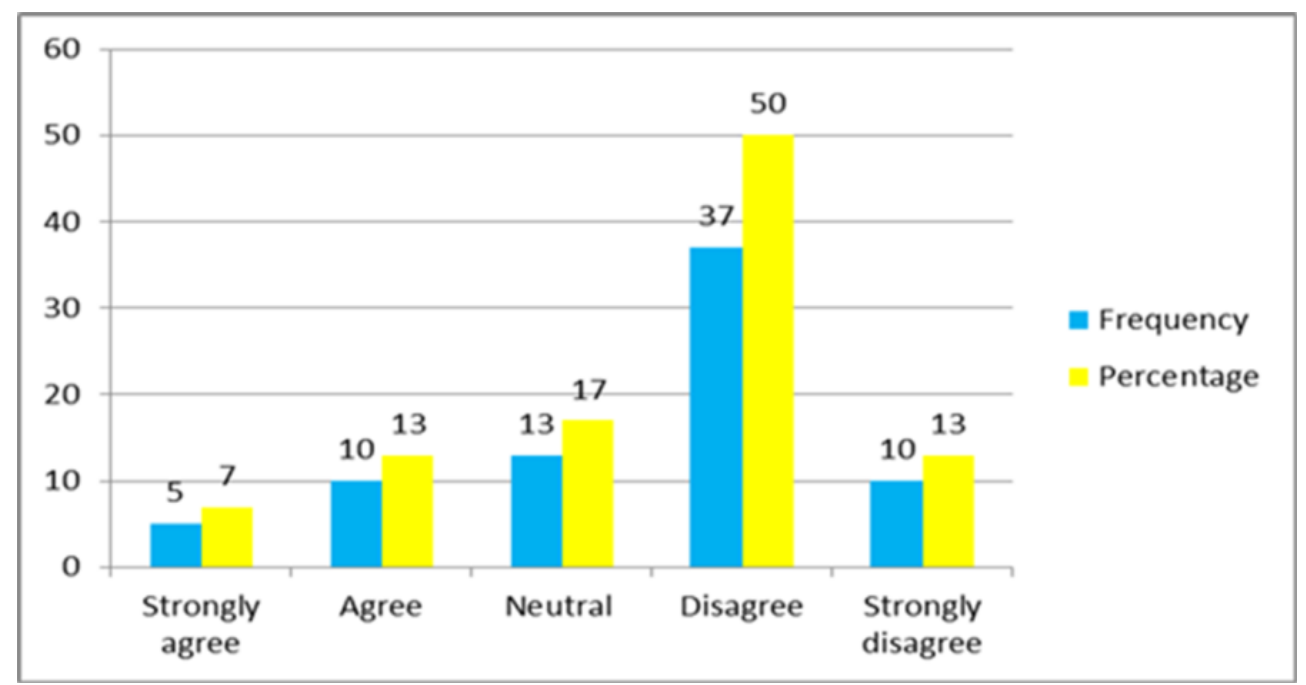

Figure 8: Company Acquires More Referrals and a Good Reputation 
As shown in Figure 9, 45 (60 percent) are neutral regarding the statement that marketing creates awareness and more popularity about their companies' brands. A small percentage ( 20 percent) agree and strongly agree and 20 percent also disagree and strongly disagree.

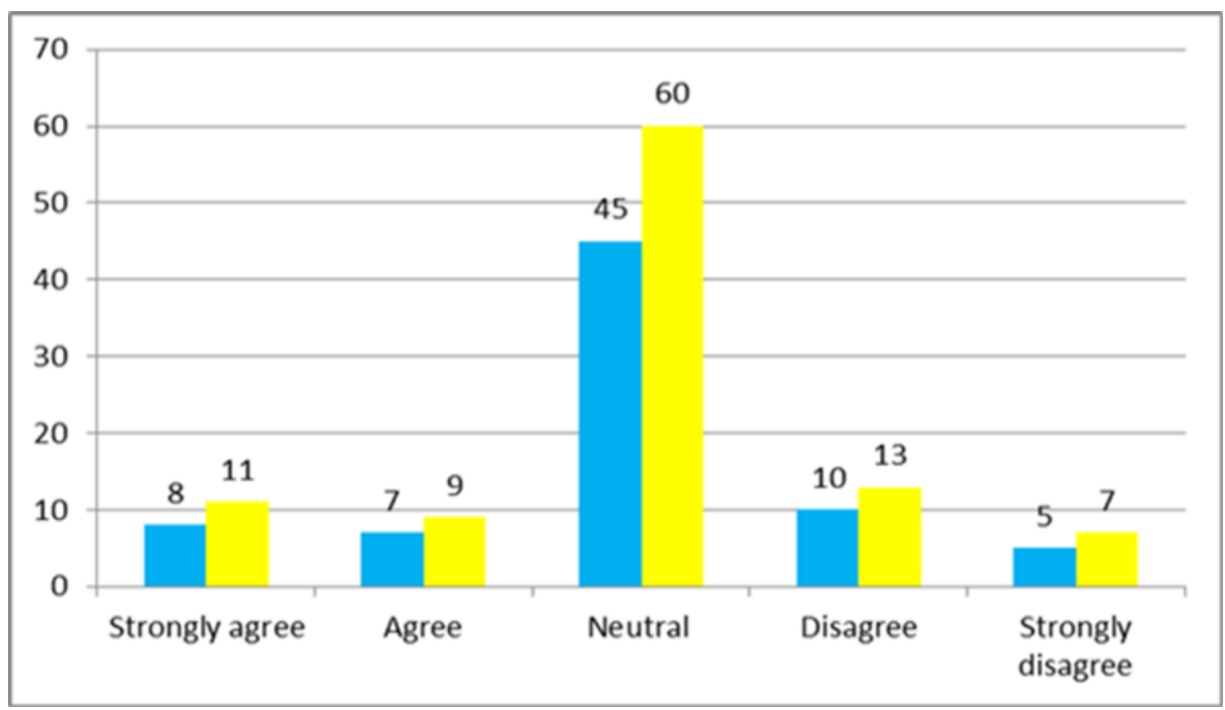

Figure 9: Viral Marketing Creates More Awareness and More Popularity about Companies' Brands

The results shown in Figure 10 reveal that 18 (24 percent) of the respondents strongly agree and 12 (16 percent) agree that viral marketing assists the company in obtaining better ideas for future improvements. A total of 16 (21 percent) are neutral, 25 (34 percent) disagree, and only four (five percent) strongly disagree.

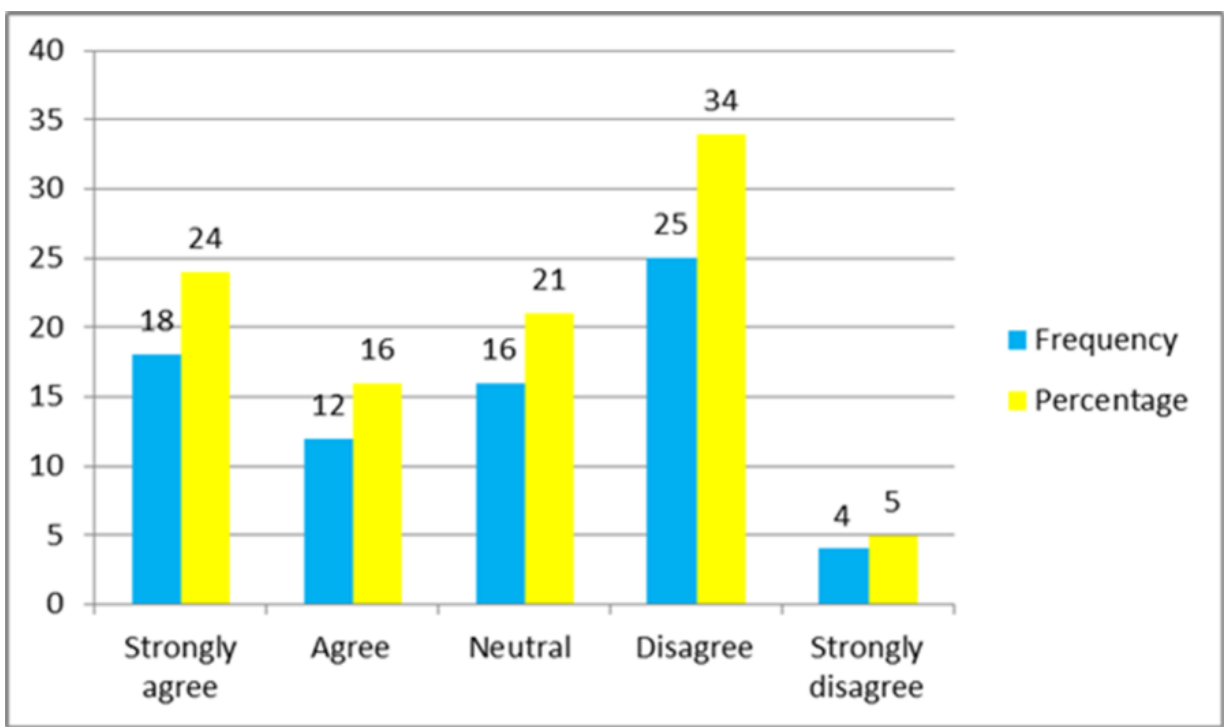

Figure 10: Viral Marketing Assists the Company in Obtaining Better Ideas for Future Improvements 
Figure 11 illustrates that 29 (38 percent) of the respondents strongly agree and 21 (27 percent) agree that viral marketing is used as a source of information about the company. Ten (13 percent) of the respondents are neutral about the statement, while 10 (13 percent) disagree and seven (nine percent) strongly disagree.

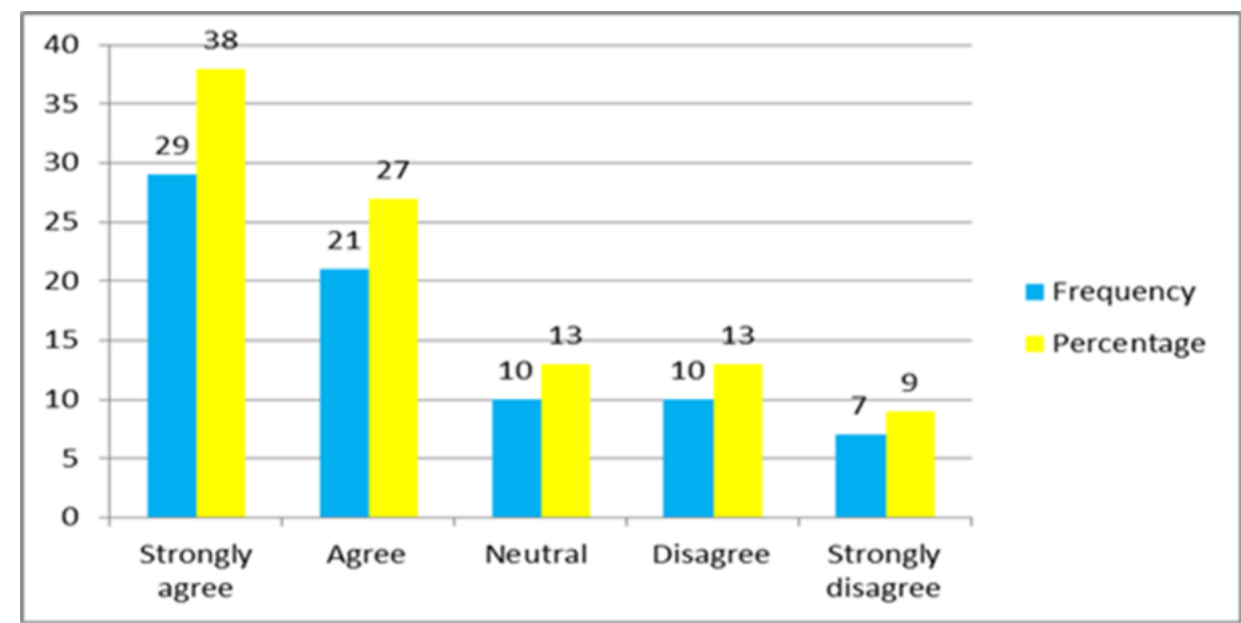

Figure 11: Viral Marketing is Used as a Source of Information about the Business/Company

As illustrated in Figure 12, 29 (39 percent) of the respondents disagree and 25 (33 percent) strongly disagree that it is easy to control information coming via viral marketing with regard to their companies. Eight (11 percent) are neutral and a small percentage (17 percent) agree (nine) and strongly agree (four).

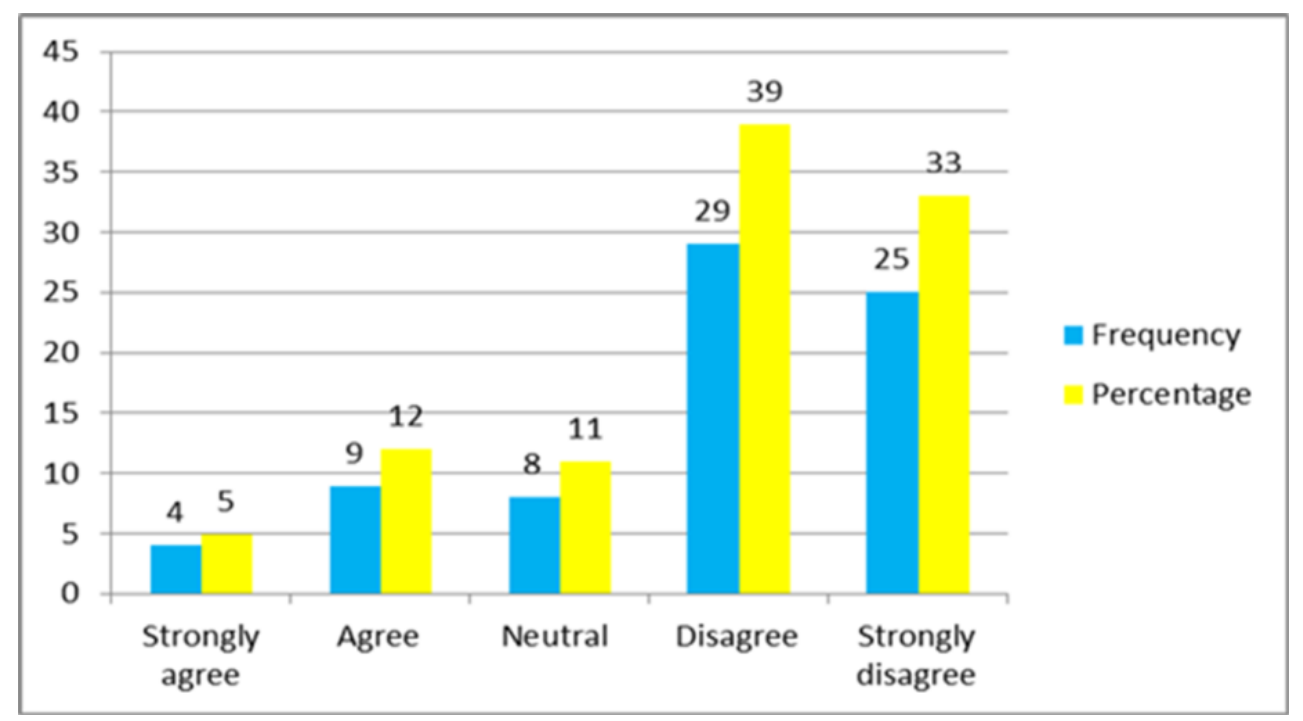

Figure 12: It is Easy to Control Information Coming via Viral Marketing, With Regard to the Company 
The results, as shown in Figure 13, illustrate that 25 (33 percent) of the respondents disagree and 27 (36 percent) strongly disagree that information and brand reputation about their companies have increased due to the use of viral marketing. Eleven (15 percent) of the respondents are neutral, while seven (nine percent) strongly agree and five (seven percent) agree.

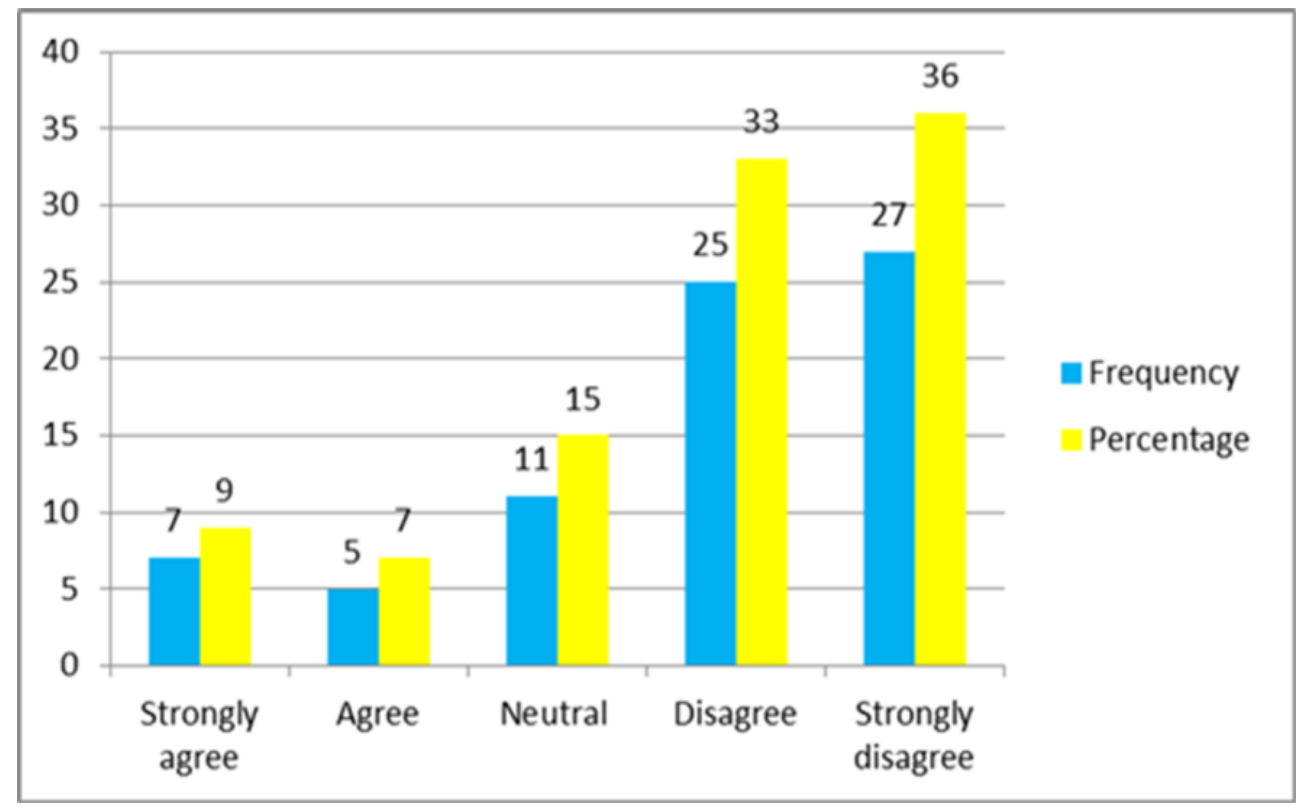

Figure 13: Information and Brand Reputation about Our Company has Increased due to the Use of Viral Marketing

Figure 14 illustrates that a large number of respondents disagree with the statement that their customers understand their responsibilities of using viral marketing, where 32 (42 percent) disagree and seven (nine percent) strongly disagree. At the same time, 17 (23 percent) are neutral, eight (11 percent) agree, and 11 (15 percent) strongly agree.

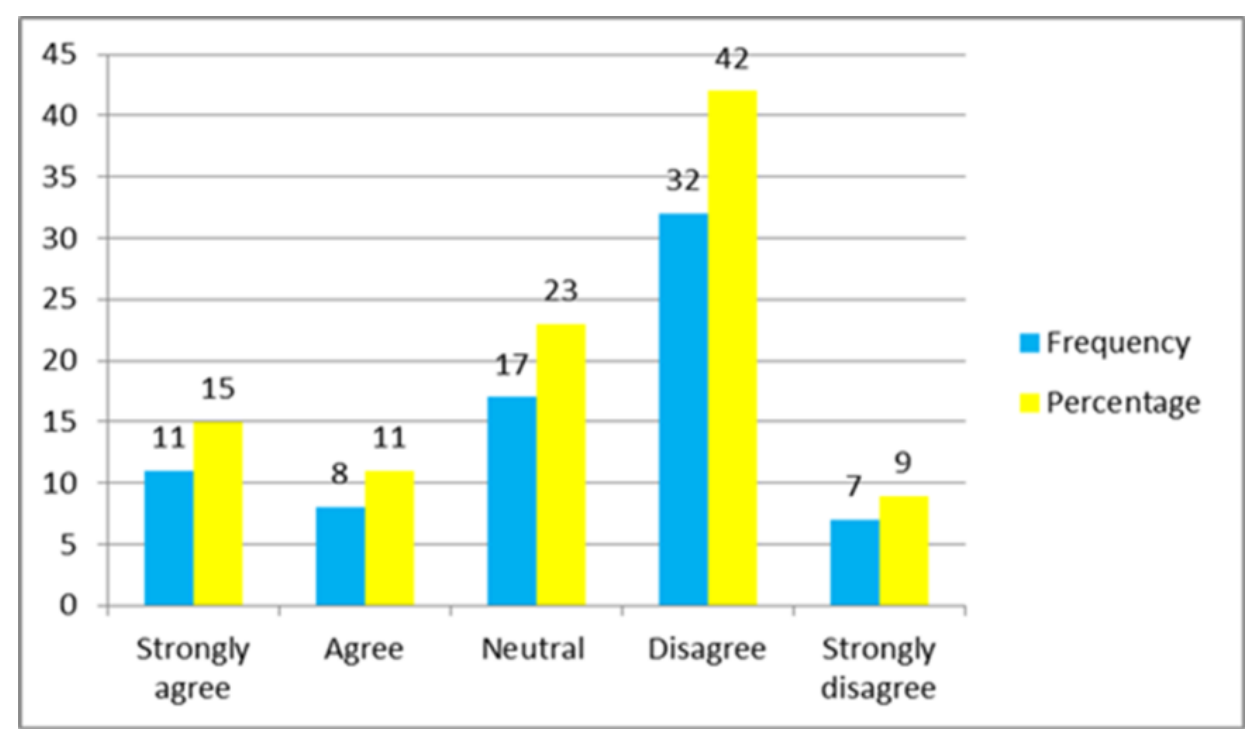

Figure 14: Our Customers Understand their Responsibilities of Using Viral Marketing 
The results illustrated in Figure 15 show that most respondents disagree that viral marketing has helped them to build a strong relationship with their target market, with 28 (38 percent) disagreeing and 16 ( 21 percent) strongly disagreeing. However, 10 (13 percent) are neutral, 12 (16 percent) agree and nine (12 percent) strongly agree.

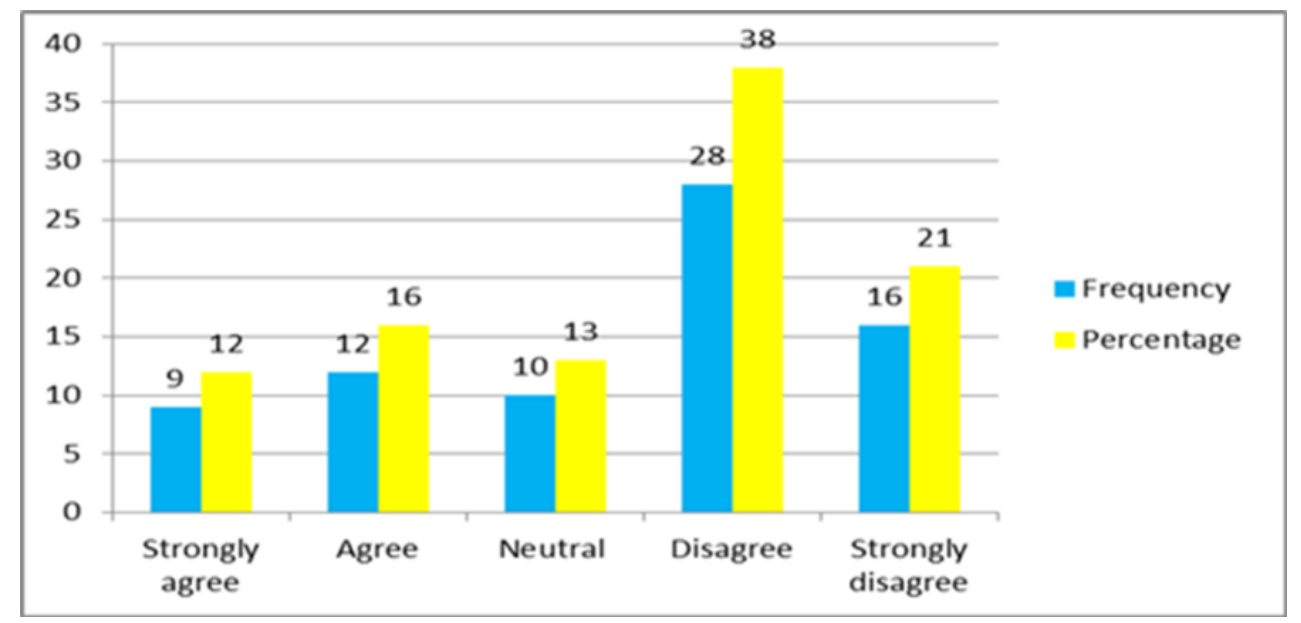

Figure 15: Viral Marketing has Helped us to Build a Strong Relationship with Our Target Customers

Figure 16 shows that most respondents believe that it is only their target customers who communicate with them through the use of viral marketing, where 23 (31 percent) strongly agree and 24 (32 percent) agree. Seven (nine percent) are neutral, 11 (15 percent) disagree, and 10 (13 percent) strongly agree.

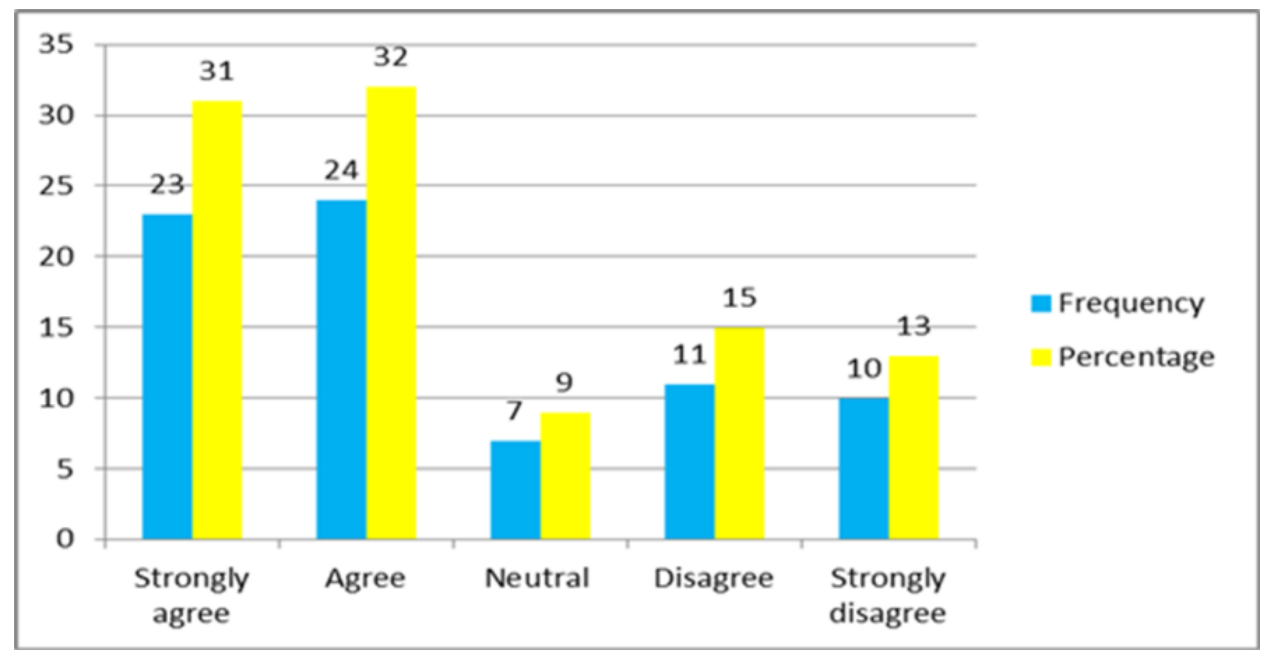

Figure 16: Only Our Target Customer Communicate with us Through the use of Viral Marketing

\section{LIMITATIONS}

This study did not cover all companies in all provinces in South Africa and was limited to only four provinces - the Eastern Cape, North West, KwaZulu-Natal, and Gauteng. Therefore, the results of the study cannot be generalized to all South African companies. Due to the size of South Africa, as well as social attributes and geographical profiles, it was difficult to research every company in every province; therefore, further research needs to include a large sample of other companies in other provinces. 


\section{IMPLICATIONS}

practice.

The implications of this study include issues related to both viral marketing theory and viral marketing

\section{Implications for Viral Marketing Theory}

In order to identify a better company marketing communication strategy, with specific reference to South African companies, marketers and all stakeholders of South African companies need to obtain a clear understanding of the relevant theories that can help to solve complex problems faced by corporate brand managers. New concepts and theories in viral marketing campaigns and strategies for companies should be proposed and implemented. The important elements for viral marketing practices in South Africa should be further emphasized. This means that South African company owners/managers need to implement viral marketing and understand its concept. This is essentially an applied viral marketing study related to marketing strategy, limiting the contribution to marketing theory. The main contribution of the study is therefore viral marketing practice.

\section{Implication for Viral Marketing Practice}

On the practical side, the results of this study clearly indicate that due largely to a lack of viral marketing knowledge and expertise, South African company marketing managers and owners/managers do not utilise viral marketing strategies as effectively in their companies as they could. Because of this lack of viral marketing skills, they might not provide a viral marketing campaign as a suitable approach or use it as a part of their marketing communication mix. Therefore, the practical implications of this study will benefit South African companies' marketing managers and all stakeholders by emphasizing a new way to consider future viral marketing activities of their companies.

\section{CONCLUSIONS}

Since the use of new technologies, such as social media and social network viral marketing, is rapidly growing in South Africa in both the business and social sectors, company marketing managers, company directors, company owners, and all affiliated company stakeholders should be made aware of the value of viral marketing in promoting their business. Cost benefits and advantages of using viral marketing as a promotional tool for strengthening the company brand must be clearly understood.

In many cases, various tools, such as buzz, word-of-mouth, and guerrilla, are being used as a part of viral marketing. However, in principle, viral marketing is to spread the word and encourage people to pass the message. Though this new form of communication is encouraged by new trends in internet users' lives, the majority of South African companies do not believe that viral marketing builds a strong relationship with their target customers nor that it increases their brand reputation. It was further found that they also believe it is not easy to control information obtained via viral marketing.

\section{RECOMMENDATIONS}

In order to enable South African companies to improve their use of viral marketing as a brand reputation promotional tool, it is recommended that more needs to be done to promote online, community, entrepreneurial knowledge skills. South African marketing managers must have thorough knowledge of the market environment; they need to know who their customers are, what they buy, how they buy, where they buy, and when they buy in order to understand and apply the right mode of communication.

It is recommended that South African marketing managers should encourage their companies to fully utilise viral marketing with the aid of social networking websites and other social media outlets such as Facebook, Twitter, LinkedIn, and individual blogs. Company marketing managers must notify target customers/users about the company social network websites' terms and conditions in place, which govern the use of the company website, to minimize negative comments. Company newsletters should also be supplied to communities in order to teach them about good communications ethics, including communicating through websites. 
South African viral marketers should also make use of a fun angle, interactivity, and rewards when developing their viral marketing as this will encourage consumers to pass the message along.

\section{RECOMMENDATIONS FOR FURTHER RESEARCH}

This study intends to establish an understanding and knowledge with regard to the impact of viral marketing on corporate brand reputation within the company, with specific reference to South African companies. Further studies on the benefits of viral marketing strategies in South African companies should be encouraged as this has the potential of increasing company brand awareness, popularity, image, trust, and ensuring long-term company and customer relationships.

Based on the findings of this study, further research could include similar studies in other South African provinces with a large sample in order to assess whether these findings are typical of all provinces. In-depth qualitative research would assist in better understanding the nature of viral marketing problems experienced by South African companies and their attitudes to viral marketing and the expenditure of financial resources on viral marketing activities. A study by the various South African company managers into the attitudes toward, and knowledge of, viral marketing would be helpful with regard to identifying ways to improve the use of viral marketing by South African companies.

\section{AUTHOR INFORMATION}

Dr. L. M. Lekhanya is a senior lecturer in the Faculty of Accounting and Informatics at the Durban University of Technology (DUT), Durban, South Africa. He has published a number of articles in refereed journals and is the supervisor for Master's and Doctoral students at many universities in South Africa. He is currently working toward publishing a prescribed textbook on entrepreneurial marketing. E-mail: lawrencel@dut.ac.za

\section{REFERENCES}

1. Aaker, D. A. (2004). Leveraging the corporate brand. California Management Review, 46(3), 10.

2. Aaker, D. A. (2011). Brand relevance: Making competitors irrelevant. San Francisco: John Wiley \& Son.

3. Abimbola, T., \& Kocak, A. (2007). Brand, organization identity and reputation: SMEs as expressive organizations: A resources - Based perspective. Qualitative market research: An International Journal, 10(4), 416-43.

4. Anon, (2011). The advantages and disadvantages of social networking. Every day-wisdom. Retrieved from http://www.everyday-wisdom.com/social-networking.html

5. Argenti, P. A., \& Druckenmiller, B. (2004). Reputation and the corporate brand. Corporate Reputation Review, 6(4), 368-374.

6. $\quad$ Baker, M. J. (2003). The marketing book. (5 $5^{\text {th }}$ ed.). London: Butterworth Heinemann.

7. Bradly, A., \& Honey, G. (2007). Corporate reputation: Perspectives of measuring and managing a principal risk. Retrieved from http://www.cimaglobal.com/Documents/Thought_leadership_docs/ Corporate $\% 20$ reputation $\% 20$ perspectives $\% 20$ of $\% 20$ measuring $\% 20$ and $\% 20$ managing $\% 20$ a $\% 20$ principal $\%$ 20risk.pdf

8. Bryant, D. (2010). The impact of viral marketing and reputation management. Retrieved from http://bryantwebservices.wordpress.com/2010/08/26/the-impact-of-viral-marketing-and-reputationmanagement/

9. Brown, D., \& Fiorella, S. (2013). Situational influence: A new marketing model for a new era. Retrieved from http://www.quepublishing.com/articles/article.aspx?p=2065721\&seqNum=4

10. Cant, M. C., \& Wiid, J. A. (2013). Establishing the challenges affecting South African SMEs. International Business \& Economics Research Journal, 12(6), 708.

11. De Bruyn, A., \& Lilien, G. L. (2008). A multi-stage model of word-of-mouth influence through viral marketing. International Journal of Research in Marketing, 25(3).

12. Dobele, A., Toleman, D., \& Beverland, M. (2005). Controlled infection! Spreading the brand message through viral marketing. Business Horizons, 48(2). 
13. De Pelsmacker, P., Geuens, M., \& Van den Bergh, J. (2010). Marketing communications: A European perspective ( $4^{\text {th }}$ ed.). England. Pearson Education Limited.

14. Du Plessis, P. J., Strydom, J. W., \& Jooste, C. J. (2012). Marketing management (6 ${ }^{\text {th }}$ ed.). Cape Town: Juta.

15. Borade, G. (2013). Advantages and disadvantages of viral marketing. Retrieved from http://www.buzzle.com/articles/advantages-and-disadvantages-of-viral-marketing.html

16. Fatoki, O., \& Garwe, D. (2010). Obstacles to the growth of new SMEs in South African: A principal component analysis approach. African Journal of Business Management, 4(5), 729-738.

17. Hutchings, C. (2012). Commercial use of Facebook and Twitter - risks and rewards. Business Horizons, 54(3), 193-207.

18. Jobber, D. (2007). Principles and practice of marketing ( $5^{\text {th }}$ ed.). New York: McGraw-Hill.

19. Kaikati, A., \&, Kaikati, J. (2004). Stealth marketing: how to reach consumers surreptitiously. California Management Review, 46(4).

20. Kaplan, A. M., \& Haenlein, M. (2011). Two hearts in three-quarter time: How to waltz the social media/viral marketing dance. Business Horizons, 54(3).

21. Klopper, H. B. (2002). Viral marketing: A powerful, but dangerous marketing tool. South African Journal of Information Management, 4(2).

22. Larson, R. J. (2009). The rise of viral marketing through the new media of social media. Faculty Publications and Presentations. Paper 6. Retrieved from http://digitalcommons.liberty.edu/busi_fac_pubs/6

23. Leskovec, J., Adamic, L. A., \& Huberman, B. A. (2008). The dynamics of viral marketing. Retrieved on June 21, 2013 from http://arxiv.org/pdf/physics/0509039.pdf

24. Mindcomet Corporation - white paper. (2008). Viral marketing: Understanding the concepts and benefits of viral marketing. Retrieved from http://cmginteractive.com/uploads/viral_marketing.pdf

25. Paul, B. (2007). Sales \& marketing on the INTERNET. Retrieved from http://search.proquest.com/docview/224130418

26. Pownall, C. (2011). Managing corporate reputation in the digital age. Retrieved from http://www.wpp.com/ /media/SharedWPP/ReadingRoom/Digital/managing_corporate_reputation.pdf

27. Rice, D. (2010). Managing your reputation in a viral world. Retrieved from http://search.proquest.com/docview/228394652

28. Richardson, M., \& Domingos, P. (2012). Evolving viral marketing strategies. Retrieved from http://dl.acm.org/citation.cfm?id=1830701

29. Singha, T., Veron-Jackson, L., \& Cullinane, J. (2008). Blogging: A new play in your marketing game plan. Business Horizons, 51(4).

30. Stoke, D. (2000). Small business management: A case study approach ( ${ }^{\text {rd }}$ ed.). London: Ashford Colour Press.

31. Van den Bergh, J., \& Behrer, M. (2011). How cool brands stay hot: Branding to Generation Y. London: British library.

32. Van der Lans, R., van Bruggen, G., Eliashberg, J., \& Wierenga, B. (2010). A viral branching model for predicting the spread of electronic word-of- mouth, Marketing Science, 29(2).

33. Wampole, H. (2012). Viral marketing: An online spin to traditional word of mouth advertising. Retrieved from www.honors.ufl.edu/apps/Thesis.aspx/Download/1302

34. Wilson, R. F. (2012a). The six simple principles of viral marketing. Retrieved from http://www.gwu.edu/ ibus266j/Global\%20E-Marketing/031300_viral.html

35. Wilson, R. F. (2012b). Viral marketing: An online spin to additional word of mouth advertising. Retrieved from www.honors.ufl.edu/apps/Thesis.aspx/Download/1302

36. Young, L., \& Burgess, B. (2010). Marketing technology as a service: Proven techniques that create value. Chichester: John Wiley \& Son. 
NOTES 